\title{
13. National counter-terrorism responses: Israel
}

\section{Doaa' Elnakhala}

\section{POLITICAL AND SECURITY CONTEXT}

Israel's counter-terrorism experience has developed in the context of its conflict with the Palestinians, which developed back in the late 19th century and was born with the establishment of the State of Israel in 1948. In the 1950s violent, non-state organisations started to appear amongst Palestinians who were displaced by the 1948 war. ${ }^{1}$ Most of those groups adopted a tactic that became known as armed resistance, to liberate their homeland of Palestine. For some of these groups, Palestine extends from the Jordan River in the east to the Mediterranean in the west, the establishment of which requires the elimination of today's Israel. Palestinian guerrilla attacks against Israel started in the 1950s when Israel faced waves of attacks by the fedayeen ${ }^{2}$ (Sayigh, 1999, p. 62; Byman, 2011, pp. 1-2), who mostly infiltrated Israel's borders from neighbouring Arab countries to perpetrate attacks against Israel. Yet it is important to recall that unlike terrorist groups like al-Qaeda and the so-called Islamic State (IS), the Palestinian armed groups have particular and small-scale goals, such as self-determination, liberation and the establishment of an independent Palestinian state. ${ }^{3}$ To Israel, these groups constitute the source of an existential threat. Existing face-to-face with such groups since their creation, the Israeli law enforcement agencies, military and intelligence services have built a unique arsenal to fight non-state violence. This has resulted in diverse counter-terrorism tactics and a sophisticated institutional design of its counter-terrorism landscape. Such characteristics are further strengthened by cutting-edge technologies, training and other capabilities.

\section{Nature of the Conflict}

While the two sides are clearly fighting over land, there is also a religious element to the conflict, given that Israel is a Jewish state and the majority of Palestinians are either Muslims or Christians. Additionally, various disputed 
sacred places constitute a central issue in the Palestinian-Israeli conflict. The Temple Mount for the Jews, and Haram al-Sharif for the Muslims, are sacred places of utmost centrality to their respective religions. The problem is that these sacred places occupy the same location (Hassner, 2009). The Western Wall for the Jews and the Wall of Tears for Muslims, as well as Hebron's Machpelah Cave for Jews and Haram al-Ibrahimi for Muslims, also share the same locations (Abou Ramadan, 2016, pp. 182-183). Until the Six-Day War of 1967, Israel had no control over the holy sites in East Jerusalem. After occupying the eastern part of the city, the issue of control over these sites was negotiated and an agreement was reached, concluding that the Dome of the Rock would continue being an Islamic waqf, or trust. Jews were allowed into the site as tourists but were not allowed to pray there, although this agreement was not respected at all times ('The struggle ...', 2015). In sum, the religious dimension adds additional complications to an already complex territorial dispute.

\section{Proliferation of Insurgent Groups}

Several armed groups were created in the diaspora after the establishment of Israel in 1948. Fatah, the Popular Front for the Liberation of Palestine (PFLP) and the Democratic Front for the Liberation of Palestine (DFLP), ${ }^{4}$ established in the 1960s and 1970s, are some of the most important groups. These groups organised together under the umbrella movement of the Palestinian Liberation Organization (PLO), which was recognised by the Arab League and the United Nations (UN) as the legitimate representative of the Palestinian people in 1974 (Giacaman, 2013, pp. 24-27). The Palestinian-Israeli conflict escalated with Israel's occupation of the Gaza Strip, the West Bank and East Jerusalem in 1967. A decade into the occupation of the Palestinian Territories, other groups appeared, this time inside the Territories themselves, the most famous of which are Hamas and the Palestinian Islamic Jihad (PIJ), which were officially established in the early and the late 1980s respectively. Several other smaller groups proliferated between 2000 and 2010; for example, the Popular Resistance Committees (Elnakhala, 2014, p. 130). The influence of the latter groups on the conflict is much more limited compared to that of Hamas or Fatah, however.

While these organisations have different ideological leanings, they all identify the liberation of Palestine (or parts of it) and the establishment of an independent Palestinian state as their goal. Moreover, all of them have carried out attacks against Israel in an attempt to attract international attention to the Palestine question, or simply to impose real or symbolic harm on the State of Israel. Some of these organisations, especially the larger and older ones, have witnessed shifts in their strategies. The Fatah leadership, for example, adapted 
its techniques in dealing with Israel, from an armed struggle in the 1960s and 1970 s, to peace talks in the 1980 s. At present, Hamas is the most militarily active Palestinian militant group on the scene.

\section{NATURE OF THE THREAT}

Generally, terrorism can undermine public confidence and security (Weisburd et al., 2009b, p. 1265). Israeli citizens feel threatened by the Palestinian militants as well as by other actors in the region at large, such as Hezbollah and Iran. Despite Israel's military might, there is a constant sense of collective insecurity and fear. These insecurities peak during periods of high tension with the Palestinians, such as in 2018 when a survey revealed that 52 per cent of Israelis feared that war was imminent ('Poll ...', 2018). Other, previous studies presented similar results and demonstrated a similar sense of fear and insecurity (Bar-Tal et al., 2009, pp. 224-225; Clarno, 2017, p. 161).

Since its last war against an Arab conventional army - that is, those of Egypt and Syria in the Yom Kippur War of 1973 - Israel has been exposed to a range of non-conventional threats, including Hamas's military capabilities and its will to attack Israel. Until the First Palestinian Intifada in 1987, terrorism was perceived among the Israeli decision-makers as an ongoing security concern. But it has since been transformed into an existential threat, a perception that further deepened after military confrontations with Hamas in 2008-2009, 2012 and 2014 (Erbay, 2012, p. 42).

Hamas today is the most threatening of the Palestinian groups espousing violence, primarily because it has made the most advanced progress in building a quasi-military capability to launch multi-faceted, complex attacks against Israel that embrace a more strategic approach, rather than simply relying on tactical nuisance attacks. Through support from Iran $^{5}$ and Hezbollah, Hamas has managed to improve and expand its fighting capabilities over time. In the past, Hamas, like other violent organisations in the West Bank and Gaza Strip, relied on roadside and settlement attacks, as well as suicide bombings. In 2001, as the political and security situation was deteriorating, Hamas and other militant groups started to use homemade rockets in attacking Israel. While these rockets were initially very rudimentary and barely caused any damage, they became more effective over time, by virtue of their increased range and destructive power. In the summer of 2014, Israel realised that Hamas's rockets had evolved into a much more strategic threat, since they landed near Israel's international airport and hit important city centres such as Tel Aviv, Ashkelon and Jerusalem. Currently, there is a concern that Hamas's attack tactics will expand to include armed drones. Until now, Hamas has mostly been using unmanned drones to collect intelligence ${ }^{6}$ (Ahronheim, 2017). Many in Israeli circles have raised doubts about Israel's ability to neutralise the threat from 
Hamas (Rabinovich, 2015, p. 4). There is some criticism within Israel of the government's approach to Hamas and the Gaza Strip at large. A report by the Israeli State Comptroller Joseph Shapira stated that there is a direct link between the siege of Gaza, the growing military strength of Hamas, and the rockets fired at southern Israeli towns and villages (Eldar, 2017).

Hamas and other Palestinian militant groups, unlike groups such as al-Qaeda and IS, are motivated by specific nationalistic and territorial goals, including ending the Israeli occupation and establishing an independent Palestinian state. They also have short-term tactical and operational goals such as conducting bombing and rocket attacks and tunnelling (to import weapons and attack Israel) that pave the way for the more strategic, longer-term goals. The persistence of its long-term goals keeps Hamas continuously motivated to attack Israel, despite all the obstacles and deterrence policies, even given it may not necessarily gain much from any specific attack, as its short-term goals are usually to inflict harm on Israel and its citizens (Elnakhala, 2014).

The years 2015 and 2016 witnessed a wave of knifing and ramming attacks, mostly conducted by young Palestinians in the West Bank, including Jerusalem and Tel Aviv. Between October 2015 and March 2016 alone, 211 stabbings of Israelis were reported, in addition to 83 shootings and 42 car-ramming attacks, resulting in the deaths of 30 Israelis and two US citizens. During the same period more than 200 Palestinians were killed, of whom more than 130 died while allegedly carrying out attacks on Israelis. Hamas claimed a small number of these attacks, although many of the attackers involved had no political affiliation. Some attributed this wave of attacks to a growing Palestinian sense of alienation and marginalisation, as well as a loss of hope for any possibility of positive change (Beaumont, 2016).

At present, the Palestinians suffer at least three hardships which if unaddressed might jointly lead to a Third Intifada: namely, economic hardship (arising partly as a result of Israeli policies), complexities of daily life (such as Israeli security checks, closures, and so on) and restrictions on freedom of movement, including visits to the holy city of Jerusalem. While the Palestinian Authority (PA) is expected to play a role in suppressing such developments, a swift deterioration is always possible. Moreover, countering an intifada usually costs many lives and absorbs multiple resources. Several Israeli and international reports warned against a humanitarian crisis in the Gaza Strip, as the result of the more than decade-long Israeli siege. Coupled with continued Israeli attacks, this state of affairs may result in a complete collapse of the economic, humanitarian, health and environmental systems, from which Israel would be far from immune (Tolan, 2018). 


\section{ISRAELI COUNTER-TERRORISM INSTITUTIONS}

\section{Intelligence Services}

Israel's first Prime Minister, David Ben Gurion, described intelligence as 'the first line of defence'. The contemporary Israeli intelligence community is still enveloped in a high level of secrecy, which to some extent has contributed to the well-being of the agencies (Rodman, 2013, p. 737). Israel has three main intelligence agencies: the Shin Bet, Mossad and Aman. While these agencies work closely together, some of their tasks overlap, which generates internal conflicts (Bitton, 2016, p. 142). The three agencies prepare an annual terrorism threat assessment for the Prime Minister, and information is usually disseminated fairly quickly amongst these agencies, as well as the Israeli security institutions (Tucker, 2008). Unlike their counterparts in most other democracies, the Shin Bet and Mossad are directly supervised by the Prime Minister's Office. In 2009, the position of the Minister for Intelligence and Strategic Affairs was created, and whilst the holder of this post is considered the ministerial supervisor of the intelligence community in Israel, the heads of the three Israeli intelligence agencies remain subordinated to other ministers, viz. the Prime Minister for the Shin Bet and Mossad, and the Minister of Defense for Aman (Bitton, 2016).

\section{Shin Bet}

Shin Bet is also known as Shabak, or the Israeli Security Agency (ISA), and is responsible for domestic intelligence, counter-espionage, internal security and the prevention of domestic terrorist acts. It is also responsible for the security of important officials, aviation and other strategic assets, as well as verifying the security clearances of members of the defence and intelligence communities, in addition to other officials (Bitton, 2016, p. 143). The Arab Affairs Division of the Shin Bet conducts political surveillance of Arab militants, while the Protection and Security Division safeguards Israeli government buildings and embassies, defence contractors, scientific installations, key industrial plants and the national airline, El Al (Tucker, 2008). Despite being Israel's domestic intelligence organisation, the Shin Bet still fulfils some foreign intelligence functions by collecting and analysing data from areas such as Lebanon and Sinai, as well as the Gaza Strip and the West Bank (Bitton, 2016). Given that the Shin Bet operates both inside Israel and in these external areas, it functions as an information bridge between the police and the military (Byman, 2011).

The powers of the Shin Bet were extended after the occupation of the Golan Heights, the West Bank and the Gaza Strip in 1967, and it became responsible for preventing the terrorist activities of residents of the Territories directed 
against Jewish and Israeli targets (Bitton, 2016; 'The Six Day War', 2020). Although it was founded soon after the creation of the State of Israel, the Shin Bet's functions, structure and powers were not comprehensively legislated until February 2002 ('The ISA Statute', 2020).

\section{Mossad}

Israel's foreign intelligence agency is known as Mossad (Hebrew for 'institute') and it was established in 1951 by former Prime Minister David Ben Gurion. The Mossad charter details the organisation's goals as:

Secretly collecting information (strategic, diplomatic and operative) outside the State's borders; conducting special operations beyond the State of Israel's borders; stopping hostile countries from developing unconventional weapons and arming themselves with them; thwarting terrorist activities against Israeli and Jewish targets abroad; bringing Jews from countries which are preventing them from immigrating and creating a defense framework for the Jews in those countries. (Bergman, 2016)

The number of Mossad official employees was estimated at around 7000 in 2018 (Rodman, 2013). Mossad spearheaded counter-terrorism efforts against the Palestinian groups operating from Jordan, Lebanon and elsewhere in the world. It also focuses on Arab nations and organisations worldwide. The agency has a foreign liaison programme that serves as the gateway for most intelligence-sharing (Tucker, 2008; Byman, 2011)

Mossad collects intelligence, largely from human sources (HUMINT). Unlike other intelligence agencies, Mossad is required not only to provide intelligence but also to carry out special operations, such as rescue missions, assassinations, and so on. Mossad's specialised unit, Caesarea, spearheads such operations. It is responsible for both intelligence relations and diplomatic relations with countries which do not have open ties with Israel. The agency is also mandated to protect the citizens of the State of Israel, but importantly, it also sees itself as the defender of all Jews in the world, and as an organisation it is required to help smuggle Jews out of hostile countries and into Israel (Bergman, 2016; Younes, 2018).

Although details of the agency's internal organisation remain obscure, it is reported that Mossad has a Collections Department, a Political Action and Liaison Department, a Special Operations Division (known as Metsada), a Psychological Warfare Department (LAP), a Research Department and a Technology Department (Ostrovsky and Hoy, 1991).

\section{Aman}

The military intelligence organisation, Aman, is an independent service and has more staff, assets and analytical capabilities than its sister organisations. Aman controls most of the signals intelligence (SIGINT) and aerial reconnais- 
sance assets necessary for counter-terrorism. Aman produces comprehensive national intelligence estimates for the Prime Minister and the Cabinet, as well as daily intelligence reports, risk of war estimates, target studies on neighbouring Arab countries and also communications intercepts. Aman also conducts cross-border agent operations. Its staff was estimated at 7000 personnel in 2011 ('The State ...', 2005; Byman, 2011).

Aman's Unit 8200 is the biggest in the military, and is also named the Central Collection Unit. Unit 8200 collects SIGINT for the military, as well as the entire intelligence community (Byman, 2011, p. 339). Moreover, Aman collects human intelligence through Unit 504, and has Israel's prime operational unit, Sayeret Maktal (special reconnaissance unit, also called Unit 269), under its command. Compared to its foreign equivalents, Aman is unique in two respects: first, its leading role in technology-based intelligence and its intelligence analysis; and second, that it holds a leading role as Israel's 'national analyst', acting as the primary, national-level intelligence analysis body in the country (Bitton, 2016). Aman's Foreign Relations Department is responsible for liaison with foreign intelligence services and the activities of Israeli military attachés abroad ('The State ...', 2005).

\section{Oversight over the intel community}

Aman is supervised by the Ministry of Defense, and Mossad and the Shin Bet by the Prime Minister. Structurally, the Director of Aman comes under the command of the Chief of Staff. Given that Aman has Israel's main research and analysis department, its SIGINT and IMINT units, as well as being responsible for other technology-based intelligence collection functions, the Israeli Minister of Defense oversees a substantial portion of the work of the Israeli intelligence community. By contrast, Mossad and the Shin Bet, which mostly specialise in the production of HUMINT, differ from similar agencies in other democracies by being supervised by the head of the government, instead of having a ministerial supervisor. Some doubts have been raised about the efficacy of any prime ministerial supervision, due to the latter's extremely busy schedule (Bitton, 2016, p. 146).

Other bodies, such as the Ministerial Committee for the Service's Affairs, also perform supervisory roles over Shabak. This Committee consists of five members, including the Prime Minister and the ministers of Defense, Justice and Homeland Security, and is the government's designated oversight body to which the Shin Bet reports quarterly (at least) on its activities. It also approves regulations by the Prime Minister to govern Shin Bet activities. ${ }^{8}$ It is unclear whether Aman and Mossad have parallel oversight ministerial bodies for their oversight. The Ministerial Committee for Security and Foreign Policy (which is hierarchically under the Cabinet) is the supreme executive forum on defence and intelligence. Consequently, the Cabinet conducts some aspects of ministe- 
rial supervision over the entire intelligence community in Israel (Bitton, 2016, p. 147).

There are other supervision and oversight mechanisms covering Israel's intelligence community. One of these is parliamentary supervision by the Sub-Committee for Intelligence and Secret Services of the Committee for Security and Foreign Affairs. Another is the Committee of Heads of Services (VARASH), which includes the directors of the three security agencies, as well as the Prime Minister's Military Secretary. A third mechanism is the legal counsel provided by various legal advisors. All three intelligence agencies are scrutinised by the Attorney General (the government's legal advisor), in addition to each agency's own internal legal advisors. This is in addition to oversight carried out via the State Comptroller, internal investigations, judicial scrutiny, non-governemtal organisations (NGOs) and media coverage (Bitton, 2016, pp. 147-148).

\section{The Israeli National Police (INP)}

The INP operates within the areas under Israeli jurisdiction, though until the mid-1990s it also operated inside the Palestinian towns. The primary responsibility of the INP is to maintain public safety by preventing crimes, investigating and resolving crimes, identifying offenders and bringing them to justice, supervising and controlling traffic, preserving public order and safety, providing prison security, and maintaining homeland security. The overarching goal of the Israeli police force is to allow Israeli citizens to continue their normal routines despite terrorist threats, and to this end, all police officers receive counter-terrorism training (Weisburd et al., 2009a, pp. 2, 10).

INP units are commanded by the Commissioner of Police, who is appointed by the government following the recommendation of the Minister of Public Security. The INP is divided into six geographical districts: Northern, Tel-Aviv, Central, West Bank, Jerusalem and Southern districts. Each district is divided into two to four sub-districts, under which there are local police stations. These levels also represent the hierarchy of command, and all are subordinate to the Commissioner and Deputy Commissioner of the National Police. Generally, the INP has two organisational units: the regular police force, usually known as the Blue Police, and the border police. It also has units such as the Civil Guards, the Operations Division and Yamam under its command (Weisburd et al., 2009a, pp. 6-7).

The INP works within a highly coordinated and centralised system through which counter-terrorism functions are delegated to subordinate levels of command, usually for reasons of operational effectiveness. The police identify their counter-terrorism role under three broad tasks: (1) early prevention, interdiction and treatment of the sources of terrorism; (2) response activities 
once the attack process has started; and (3) post-attack response activities, following the attack. Additionally, the police assist with the investigation into violent attacks through the Identification and Forensic Science Unit.

The INP also has authority over the Civil Guard, the largest voluntary organisation in Israel, that was formed in 1974 with the goal of fighting terrorism and crime. Armed by the police, the Civil Guard volunteers assist the INP in all domains and all over the country. Additionally, the Civil Guard is considered an important instrument to foster police-community relations (Weisburd et al., 2009a, p. 8).

The Israeli Border Police division, a subordinate of the INP established in 1950 , is commissioned to protect Israeli ports, border towns and the zones between Palestinian and Israeli areas. The Border Police plays a central role in policing towns with special security concerns, such as Jerusalem. It also functions as an auxiliary for the military to preserve order in the Palestinian Territories, and it participates in securing the borders. The border guards formed about one-third of the INP personnel around 2010 and are recruited as part of the national military draft, and thus their uniform is military green, rather than blue. Border guards have a counter-terrorism unit, known as Yamam, established in 1974. It also carries out offensive missions, such as the interception and arrests of militants and special missions such as hostage rescue (Weisburd et al., 2009b, p. 1261; Byman, 2011).

The INP works closely with private security firms and plays a central role in supervising private security activities. In Israel, all malls, shopping areas, restaurants, hospitals, office buildings or any other public spaces have private security guards who check customers entering the facility and conduct other activities. Cooperation with these firms reduces the chances for violent actors to reach certain public facilities (Weisburd et al., 2009b, pp. 24-25). Experts note that the military model is deeply rooted in the organisation, culture and procedures of the INP. The continuing strong links between the police and the military, especially in their cooperation in the Palestinian Territories and the role of the border guards, provide strong structural differences that distinguish Israel from Western democracies (Weisburd et al., 2009b, pp. 6-7, 10).

\section{The Military}

The Israeli military, known as the Israeli Defense Forces (IDF), ranks among the most battle-tested militaries in the world. Its security objectives are 'to defend the sovereignty and territorial integrity of the State of Israel, deter all enemies, and curb all forms of terrorism that threaten daily life' ('The state ...', 2005). Its main tasks include: protecting the peace agreements; ensuring overall security in the West Bank in coordination with the Palestinian Authority; fighting terrorism inside and outside Israel; and maintaining a deterrence capability 
to prevent the outbreak of hostilities. The Israeli military has three service branches: Ground Forces, Air Force, and Navy, all of which function under the unified command of the Chief of the General Staff, who in turn is responsible to the Minister of Defense and is personally appointed by the government, on the recommendation of the Prime Minister and Minister of Defense ("The state ...', 2005; Ganor, 2007, p. 227). The military is not legally empowered to engage in ordinary police functions within the borders of the State of Israel, yet in the Palestinian areas, which are under military occupation, it is the military which has primary responsibilities for violent activities. During military operations in the territories, the Israeli military uses assistance from the INP (Weisburd et al., 2009a, p. 9).

Despite the questionable effectiveness of any regular army in fighting an irregular war, Israel heavily relies on its military in its counter-terrorism activities and, more generally, in its attempts to suppress Palestinian militancy. One of the unique features of the experience of the Israeli military is its presence in the Occupied Territories, which requires direct involvement in fighting non-conventional battles. Early on, the operations of the Israeli army were conventional missions that quickly switched to imposing curfews, administering prisons for the detention of Palestinians and suppressing public protests. The army also established and manned checkpoints between the Palestinian Territories and Israel, as well as inside the West Bank, to prevent militants from entering Israel (Erbay, 2012, pp. 42-44).

It was the First Intifada that motivated the army to consider 'terrorism' a top priority, which is in turn a product of a change in the official perception of the Palestinian violence, from an ongoing security concern to an existential threat. This required reforms in the army's fighting style, operationally and tactically. On the ground, the army switched from reliance on an aggressive, offensive style, which had previously been successful when fighting Arab armies, to a 'war of attrition' style, which required long commitment from the military, as well as additional economic resources. By 1990, the army became accustomed to fighting non-state actors and it focused on achieving satisfactory outcomes with an emphasis on a minimal loss of soldiers, rather than aiming for a decisive victory. Additionally, to respond to these changing circumstances, the army established new units to suppress demonstrations (Erbay, 2012, pp. 42-44).

In the late 1990s, the Israeli military improved its intelligence collection and sharing capabilities in order to better able it to fight an asymmetric war. After about a decade of relative calm and peace negotiations, a controversial visit by former Israeli Prime Minister Ariel Sharon to the courtyards of the al-Aqsa Mosque ignited the Second Palestinian Intifada in September 2000. The Second Intifada witnessed the use of more deadly tactics by Palestinian militants, such as suicide bombings and short-range rockets, in addition to 
traditional tactics such as roadside bombings and sniping attacks. Within this context, the Israeli military responded by also employing more lethal weapons and tactics, such as F-15 and F-16 fighter aircraft, Apache and Cobra attack helicopters, and Merkava main battle tanks (Erbay, 2012, p. 45). However, this time the military had adapted to fighting an urban war, such as using engineering units equipped with heavy machinery to break through walls and disarm enemy booby traps (Byman, 2011).

\section{ISRAELI COUNTER-TERRORISM LEGISLATION}

\section{New Israeli Anti-Terror Law of 2016}

The Israeli Anti-Terror Law provides the authorities with the tools needed for counter-terrorism efforts. It also attempts to coordinate the relevant legislations, which are largely dispersed in a number of statutes. Once enacted, the new law replaced, but did not revoke, the 1945 Defense (Emergency) Regulation. A key concept underlying this comprehensive legislation is that terrorism is a complex activity, employing various methods and with a variety of goals, and thus requiring a multi-faceted and robust response (Rosenzweig and Shany, 2010).

Approved by the Knesset in mid-2016, the law was heavily criticised for its vague definition of terrorism. It was additionally criticised for not distinguishing between attacks on civilians and attacks upon military personnel. Furthermore, its loose criteria for designating terrorist organisations meant that some non-governmental humanitarian organisations were deemed to be designated terrorist organisations, and as a result, their work was adversely affected. The legislation also allows for administrative detention, and provides the Shin Bet with wide-ranging powers to hack into the private devices of citizens, thereby potentially infringing the right to privacy. Several lawyers and human rights organisations additionally criticised the law for equating the opposition to Israel's occupation of the Palestinian Territories, including public protests and public support of victims, with committing terrorist acts. It also enables the use of 'secret evidence' in order to take preventative measures against these activities, which impedes any possibility of objecting to repressive decisions ('Israel's new Anti-Terror Law ...', 2016)

\section{Other Israeli Counter-Terrorism Laws}

In the use of its counter-terrorism tactics, Israel has relied on a myriad of laws and regulations, some of which are inherited from the era of the British Mandate for Palestine which ended in 1948. While there are laws and regula- 
tions that directly address the issue of terrorism, others deal with the matter indirectly (Salzberger, 2016, p. 4).

The declaration of the 'state of emergency' brought with it legislation that permitted a raft of preventive and punitive measures, and enabled the government to introduce regulations that overrode existing legislation. The state of emergency is renewed every year by the Knesset ('Declaring a State of Emergency', n.d.; Omer-Man, 2016). The Defense (Emergency) Regulations of 1945 were enacted by the British High Commissioner as a result of tensions between Jews and Arabs in Mandate-era Palestine. The Israeli Anti-Terrorism Law (see above) is intended to replace these regulations ('Defense (Emergency) Regulations', n.d.; Salzberger, 2016). The Prevention of Terrorism Act of 1948, which was last amended in 1993, is legally in force whenever a declaration of emergency is in operation. By enacting this Act, Israel recognises that Palestinian non-state violence is a danger beyond the general state of emergency and must be directly addressed ('Israel's Prevention of Terrorism Ordinance (September 1948)', 1948; Buhler, 2010).

The Emergency Powers Detention Law (1979) allowed the Minister of Defense to detain a person based on 'reasonable grounds to presume that such detention is necessary for reasons of state security or public safety' (Chen and Hamilton, 2006). This law applies to Israeli territory; that is, not to the Gaza Strip or the West Bank. The Order Regarding Administrative Detention no. 1591 (5767-2007) is applied in the West Bank, which falls under Israeli military rule. According to this Order, the military commander can detain a person for a maximum period of six months, with the possibility for this to be renewed indefinitely. In some cases, prisoners have been held without charge or trial for several years (Nakhala and Hakala, 2012, p. 5). The Internment of Unlawful Combatants Law (2002) enables Israel to detain members of violent and guerrilla groups, including the so-called 'cook in the Hezbollah Kitchen' ${ }^{9}$ Unlike prisoners of war, those interned may or may not face criminal charges. ${ }^{10}$ Unlike those arrested for criminal charges, there is no fixed-term limit for detention (Byman, 2011). This law additionally provides the legal basis for holding Gaza Strip residents under administrative detention.

\section{ISRAELI COUNTER-TERRORISM STRATEGY AND TACTICS}

There is no official Israeli doctrine defining the country's overall counter-terrorism strategy, but Israel's actions in this domain are guided by conceptual and operational guidelines. Generally speaking, deterrence, prevention and retaliation are at the heart of Israel's counter-terrorism policies (Freilich, 2015, p. 363). In Israel, the first priority is usually intelligence, then counter-terrorism operations, and finally, defence and civil protection. 


\section{Intelligence}

Israel has developed a highly coordinated and efficient intelligence apparatus. Israeli government agencies work continuously to identify violent operatives and cells, employing human and technological means. Intelligence classifies threats into three categories: first, those that appear imminent and require immediate attention; second, those that are less probable but could emerge in future; third, those that are unlikely to happen but are still possible (Tucker, 2008).

According to security experts, the average Israeli is highly aware of suspicious packages, individuals and actions that could pose a threat to public safety, and they would not hesitate to notify the police. In the mid-2000s, ordinary citizens foiled more than 80 per cent of attempted attacks in Israel. ${ }^{11}$ Moreover, Israeli government agencies gather human intelligence on violent actors by deploying undercover officers in the Palestinian areas and by recruiting covert human intelligence sources inside, or close to, violent organisations (Tucker, 2008; Magid, 2018).

Interrogation during detention is another important source of human intelligence in Israel, and the Israeli security agencies frequently round up and interrogate Palestinian suspects and their associates. Some coercive interrogation methods used by Israeli interrogators are deemed to be torture by human rights organisations. Indeed, torture was legalised for a period. Interrogation of suspects in Israel routinely involves the use of threats, coercion and rewards ('Torture and abuse ...', 2017).

Israel has developed sophisticated technologies for signals intelligence, imagery intelligence using unmanned aerial vehicles (UAVs), and detecting explosives and weapons at a stand-off distance. Nevertheless, Israeli intelligence agencies give priority to human intelligence over some of these other high-tech methods (Tucker, 2008).

\section{Limited and Wide Invasions}

Israel often launches military operations to disrupt militant networks in the West Bank and the Gaza Strip by cracking down on violent cells, seizing their arms, attacking bomb factories, neutralising safe-houses, and arresting or killing key leaders and bomb-makers. One of the focal goals of these operations is to prevent Palestinian militants from the West Bank and the Gaza Strip from infiltrating Israel to stage attacks. With a shift amongst Palestinian militant groups from suicide bombing to rocket attacks, these operations mostly target Palestinian short-range rocket capabilities (Tucker, 2008).

These operations were largely employed by Israel after the escalation of violence in late 2000. Some of those operations were limited; that is, rapid 
incursions aiming at the capture or killing of wanted activists, the destruction of organisational structures and facilities of violent groups, and so on. Such operations are usually short, and have a clear and specific target. Other operations are more extensive and could continue for weeks or even months, such as the partial re-occupation of Palestinian cities or areas, like those seen in Operation Defensive Shield in 2002 and Operation Cast Lead in 2008-2009.

\section{Assassinations}

In the Palestinian Territories, both the Israeli military and the Shin Bet have the final decision in a planned assassination. The Shin Bet approves the intelligence to ensure the plan is accurate, while the military decides whether or not to execute the strike, and which weapon platform to use. Israel has used a variety of methods to execute assassinations, including missiles launched by helicopter and tank, aimed at cars and homes of suspects, while more recently UAVs have become one of the most frequently used platforms (Byman, 2011, p. 319).

Assassinations of militant leaders and bomb-makers, usually conducted by the Shin Bet, Mossad or military undercover units, are particularly controversial in Israel. Advocates argue that this tactic not only interdicts imminent attacks but also undermines the militant group's stability and morale, increases tensions and rivalries among would-be successors, and forces the militants to devote resources to hiding and protecting their leadership. Nevertheless, assassinations in the Israeli context raise complex issues of legality, cost-effectiveness (Tucker, 2008) and ethics, especially the potential killing of innocent people in the vicinity of the strike (Byman, 2011).

In early 2002, a number of rules were brought in regarding Israeli assassinations policy. As of that date, assassinations became possible only if:

1. They are well supported by information that the suspect has organised attacks in the past and is planning to carry out another in the near future.

2. Appeals to the Palestinian Authority to arrest the suspect have been ignored.

3. Attempts by Israeli troops to arrest the suspect have failed.

4. The killing is not intended as retribution for violent past acts, but is designed to prevent an incipient attack that is likely to inflict multiple casualties (Tucker, 2008).

\section{Detention}

The number of Palestinian security prisoners in Israeli prisons usually peaks during times of escalations. In 2002 alone, for instance, Israel detained 1456 
Palestinians; while in 2007, more than 9000 were in Israeli detention centres (Byman, 2011). Israel uses different forms of detention when dealing with Palestinian violence. Once a Palestinian is detained for terrorism offences, they are either tried before an Israeli military court or detained administratively (Guiora, 2007, p. 522). As of January 2020, there were at least 4520 Palestinians held in Israeli prisons for security reasons. Moreover, 527 more Palestinians were held in Israel Prison Service facilities for being in Israel illegally, and are thus considered as criminal offenders by the Israeli legal system. Additionally, several dozen Palestinians are held at military facilities for short periods of time ('Statistics on Palestinians ...', 2020).

Administrative detention is detention without charge or trial, and is authorised by an administrative order rather than by judicial decree. Generally speaking, international law permits administrative detention only under stringent restrictions. Specifically, administrative detention can be used only in very exceptional cases, as the last means available for preventing danger that cannot be thwarted by less harmful means ('Administrative detention', 2017). In these cases, the Shin Bet orders that the intelligence information cannot be shared with an open court of law, and thus the concerned person can be detained administratively after approval from the Israeli military legal advisor. The West Bank or Gaza Strip Israeli military commander then signs a detention order, after which the person is brought before a military judge for a review of the intelligence leading to the detention, rather than a full, legal trial. If approved, the detention order is reviewed by a higher-ranking military judge and petitions can be filed to the High Court of Justice. The first six months of administrative detention are indefinitely renewable, but each extension is reviewable by an independent judiciary, and although the defendant has a right to a lawyer, witnesses are not called (Guiora, 2007; Byman, 2011).

Use of administrative detention in Israel has become particularly problematic, since Israel has repeatedly used administrative detention for rather vague reasons and has imprisoned many Palestinians for years, without them going on trial (Nakhala and Hakala, 2012).

\section{Control Measures}

While some Israeli control measures, such as checkpoints, roadblocks and the like, are aimed at reducing violence, it is also true that the use of these measures has greatly increased over the past two decades or so (Rijke, 2020). The reasoning behind these measures is threefold. First, the tactics detailed in this section help the authorities to separate the Israelis from the Palestinians, thereby limiting militants' access to their targets. The second justification pertains to the imposition of tight controls over border crossings. These measures serve to funnel the movement of militants through specific crossing points, 
which makes detection easier, and also facilitates the disruption of violent operations before they can attack their targets. Third, these control measures also make it easier for Israel to lock down the Palestinian areas, in the event of attack warnings, or directly after an attack. These latter measures assist with locating and detaining suspects. The control methods employed by Israel mostly utilise barriers, checkpoints and closures, but also rely on security cooperation with the Palestinian Authority.

The first Israeli barrier was built around the Gaza Strip in the mid-1990s in reaction to the emergence of Palestinian suicide bombings (Elnakhala, 2014). Finished by mid-1995, the construction of the Gaza fence came with a sophisticated system of buffer zones, magnetic cards and permits that tightly controlled the movement of any Gazan in and out of the Strip. The barrier itself has four crossings: Erez, Karni, Kisufim and Sufa. It was also complete with a number of interlocking systems, all of which were upgraded over time, including buffer zones, sensors, surveillance, and military technologies including the 'iron dome' anti-missile defence system designed to intercept and destroy incoming Palestinian rockets (Byman, 2011; Elnakhala, 2014; Elster et al., 2019).

Following a wave of suicide attacks, a second Israeli barrier was built in the West Bank amid intense international criticism, since it deviates from the agreed Green Line (Byman, 2011). ${ }^{12}$ Despite claims that this barrier was intended to separate the West Bank Palestinians from Israel, in practice it does not achieve this (Elnakhala, 2014). The barrier largely runs through Palestinian lands, and its genesis came from a wave of suicide attacks (Byman, 2011), although it did not make Israeli control over the movement of Palestinians any easier. The barrier is surrounded by an intrusion detection system on both sides, plus video cameras, other sensors, soft dirt strips to detect footprints, military-patrolled roads, deep ditches and razor wire entanglements. If completed, the West Bank barrier will run over $700 \mathrm{~km}$. Today, the construction is on halt at a length of $400 \mathrm{~km}$ (Byman, 2011; Elnakhala, 2014).

As mentioned above, Israel has developed other mechanisms to control movement of Palestinians and to close off Palestinian areas, including checkpoints, roadblocks and closures. These policies pre-dated the barrier-building, though they did become part of the barrier regime described in the previous paragraphs ('Checkpoints', 2011). In the Gaza Strip and the West Bank, Israel's closure policy started in 1967, but in 1972 Israel emphasised the economic integration of the Palestinians and granted them freedom of movement ('Checkpoints', 2011). ${ }^{13}$ Israel also started to set up a checkpoint regime, and requested different sorts of movement permits for Palestinians, through the introduction of a magnetic card system for border crossings. ${ }^{14}$ In early 1991, Israel officially revoked the general exit permits of 1972, and every Palestinian from the Palestinian Territories was henceforward required to hold a personal 
exit permit in order to enter Israel and East Jerusalem. This permit policy became more restrictive in 1993, and even more so in 2000. After signing the Oslo Agreement in 1993, Israel introduced its system of closures which sealed off access to Israel and East Jerusalem, enforced through a series of checkpoints ('Checkpoints', 2011; 'The humanitarian impact ...', 2012). Until today, Israel alone decides who can enter and exit the Palestinian Territories.

\section{Counter-Terrorism Technology}

Over time, Israel has developed a cutting-edge security and military industry that markets counter-terrorism technology, products and services throughout the world. Some scholars describe Israel as the 'capital of homeland security', since Israeli homeland security and surveillance products and services are aimed at helping not only the Israeli government but also foreign governments to conduct their operations more efficiently and cost-effectively. The technology variable is a cross-cutting element as it is used in all of the counter-terrorism tactics detailed above. Israel's surveillance technologies, for example, are highly efficient in intelligence-gathering, while its modern weaponry is used to effectively eliminate militant leaders, and a wide variety of technologies and sensors are installed on Israeli security barriers and in commercial aviation facilities (Gordon, 2011, pp. 153-154). ${ }^{15}$

The Israeli military and the state-owned military industry have had a great impact on the country's technology sector, especially as this sector was initially propagated by the military and the security establishment, an effect that can be traced back to its pre-state, Zionist history. Israel's aerospace industry, established in 1953, is the country's largest military exporter, and following the establishment of associated private companies in the 1950s, this sector now exports 25 per cent of Israel's arms sales. These developments were empowered by Israel's research and development division, known as RAFAEL, also established in the 1950s as part of the state-owned military sector (Vekstein and Mehrez, 1997). In recent years, Israel has consistently been ranked among the top ten military exporters worldwide ('Top 10 arms exporters', 2019).

\section{CONCLUSIONS}

Unlike other contemporary liberal democracies, Israel's involvement in counter-terrorism should be examined within the context of a complex territorial and religious conflict. In contrast to terrorist groups such as al-Qaeda and IS, the Palestinian violent groups involved in attacking Israel have specific and small-scale goals that can be summarised as self-determination, liberation from occupation and the establishment of an independent Palestinian state. For its part, Israel regards the threat from such groups as existential. 
The Israeli intelligence, military and police agencies have a great deal of experience in countering violent actors. As a result, they have developed and adapted their understanding of terrorism and how to respond to it. They have designed an efficient, highly sophisticated, institutional arrangement and set of counter-terrorism measures, backed by cutting-edge technologies, advanced training and other capabilities. There have been recent efforts in Israel to consolidate its laws for dealing with terrorism, by ratifying an Israeli anti-terrorism law, but Israel continues to rely on a number of other laws. These laws seem to be problematic, however, as they severely restrict freedom of association and expression among the Palestinian minority in Israel and the Palestinian population in the Gaza Strip and the West Bank. Studies of counter-terrorism refer to Israel as a leading example for other liberal democracies facing violence by non-state actors. The Israeli strategy aims at deterrence, prevention and retaliation, and uses a large suite of tactics to fulfil these goals.

\section{NOTES}

1. Before 1948, some local armed Palestinian-Arab groups attacked Jewish property and Jewish interests in Palestine, but most of this effort was not coordinated. Additionally, they had much less sophisticated military training and equipment than the Jewish militias. Research on such groups shows that the Palestinian armed groups of the 1930s and 1940s had no military training at all, and that most members were, in fact, merely males who owned rifles (Morris, 2004, p. 29).

2. Arabic for those who are willing to sacrifice their life, usually for their homeland.

3. The author refrains from describing the Palestinian groups as 'terrorist', for several reasons. First, despite various serious efforts at defining the term, the concept of 'terrorism' is generally vague, which mostly stems from the fact that terrorism is always perceived in relative terms. Second, there is no agreement on who designates whom as a terrorist. For instance, Israel and the United States designate Hamas, while the United Kingdom and Australia designate only the armed wing of Hamas as terrorist. Many other countries do not designate any Palestinian group at all. Third, Hamas was designated a terrorist group by the European Union (EU) until 2014, when the European Court removed Hamas from the proscribed list. Following an appeal by the EU Commission, the European Court decision was suspended in 2017 and Hamas was listed again. The point is: the issue of casting any group in this context as terrorist raises many contentions, which the author would prefer to avoid. Alternatively, the terms 'violence' and 'militancy', as well as their derivatives, are used.

4. Fatah and PFLP were established by the Palestinian diaspora between the 1948 and 1967 wars. The DFLP was split from the PFLP in 1969.

5. Iran poses a conventional military threat to Israel at the regional level. Yet, so far, its involvement in the conflict has been indirect, in what can be called a proxy war, through backing Hamas.

6. Other non-state actors - that is, Hezbollah - launched Ababil drones against Israel in the 2006 war.

7. Peer organisations in other countries are mostly civilian.

8. These regulations have to be approved by the Knesset as well. 
9. This implies that anyone who is linked with Hezbollah can be detained under this law.

10. Prisoners of war do not necessarily face criminal charges. Normally, they are held prisoner until the cessation of hostilities.

11. Detailed studies were carried out covering the role of the citizens in reporting suspicious objects and threats (Jonathan-Zamir et al., 2014).

12. The Green or Armistice Line is a product of agreements signed in 1948 between Israel and Egypt, Syria, Lebanon and Jordan under UN mediation. The Armistice Lines overlapped the borderlines of British Mandate Palestine, except for the West Bank and the Gaza Strip. In these two areas the lines were determined by the outcomes of war between the Jewish militias and the Arab countries in 1948 ('The Constituent Assembly ...', 1949).

13. Palestinians were not allowed to exit their areas of residence.

14. This could be in response to the First Palestinian Intifada (1987-1991); international developments, for example negotiations between Israel and the PLO, and the Gulf War; and/or simply development in the separation ideology in Israel.

15. To list a few examples, clients of Israeli technologies include American Express, City Bank, JP Morgan Chase, the US Federal Aviation Authority, the European Space Agency, Motorola and Intel (Gordon, 2011).

\section{REFERENCES}

Abou Ramadan, M. (2016) 'The Harm al-Sharif in Jerusalem: an Israeli law perspective', in Ferrari, S. and Benzo, A. (eds), Between Cultural Diversity and Common Heritage. New York: Routledge, pp. 175-190.

'Administrative detention' (2017) B'Tselem. Available at: http://www.btselem.org/ administrative detention (accessed: 5 June 2017).

Ahronheim, A. (2017) 'IDF intercepts Hamas drone flying into Israeli territory', Jerusalem Post. Available at: https://www.jpost.com/Israel-News/IDF-intercepts -unmanned-Hamas-drone-flying-into-Israeli-territory-482401 (accessed: 27 April 2020).

Bar-Tal, D., Magal, T. and Halperin, E. (2009) 'The paradox of security views in Israel: a social-psychological explanation', in Barak, O. and Sheffer, G. (eds), Existential Threats and Civil-security Relations. New York: Lexington Books, pp. 219-247.

Beaumont, P. (2016) 'Israel-Palestine: outlook bleak as wave of violence passes six-month mark', Guardian. Available at: https://www.theguardian.com/world/ 2016/mar/31/israel-palestine-violence-knife-attacks-west-bank-gaza (accessed: 27 April 2020).

Bergman, R. (2016) 'One of the worlds most mysterious organizations gets a new boss', Ynetnews. Available at: https://www.ynetnews.com/articles/0,7340,L-4748923,00 .html (accessed: 6 June 2017).

Bitton, R. (2016) 'In law we trust, the Israeli case of overseeing intelligence', in Goldman, Z.K. and Rascoff, S.J. (eds), Global Intelligence Oversight: Governing Security in the Twenty-First Century. New York: Oxford University Press, pp. 141-174.

Buhler, E.G. (2010) 'The Israeli Prevention of Terrorism Ordinance and its impact on the quality of democracy', Stanford Journal of International Relations, 11(2), pp. 58-63. 
Byman, D. (2011) A High Price: The Triumphs and Failures of Israeli Counterterrorism. New York: Oxford University Press.

'Checkpoints' (2011) JMCC. Available at: http://www.jmcc.org/fastfactspag.aspx ?tname $=44$ (accessed: 10 March 2017).

Chen, D. and Hamilton, C. (2006) Prosecuting Terrorists: A Look at the American and Israeli Experiences. Available at: http://www.washingtoninstitute.org/poli cy-analysis/view/prosecuting-terrorists-a-look-at-the-american-and-israeli-experien ces.

Clarno, A. (2017) Neoliberal Apartheid: Palestine/Israel and South Africa after 1994. Chicago, IL: University of Chicago Press.

'Declaring a State of Emergency' (n.d.) Knesset. Available at: https://knesset.gov.il/ lexicon/eng/DeclaringStateEmergency_eng.htm (accessed: 14 April 2020).

'Defense (Emergency) Regulations' (n.d.) B'Tselem. Available at: http://www.btselem .org/legal_documents/emergency_regulations (accessed: 22 February 2017).

Eldar, S. (2017) 'Has Israel recognized link between Gaza blockade, security threat?', Al-Monitor. Available at: http://www.al-monitor.com/pulse/originals/2017/03/israel -gaza-war-2014-state-comptroller-report-blockade.html (accessed: 23 March 2017).

Elnakhala, D. (2014) 'Walls and fences: the making of good neighbors?!', PhD dissertation, Government Department, University of Texas at Austin.

Elster, Y., Zussman, A. and Zussman, N. (2019) 'Effective counter-terrorism: rockets, iron dome, and the Israeli housing market', Journal of Policy Analysis and Management, 38(2), pp. 308-337. doi: 10.1002/pam.22114.

Erbay, T. (2012) 'The role of the military in counterterrorism: unintended consequences', MA thesis, Department of Security Security Affairs, Naval Postgraduate School.

Freilich, C.D. (2015) 'Israel's counter-terrorism policy: how effective?', Terrorism and Political Violence, 29(2), pp. 359-376.

Ganor, B. (2007) 'Israel, Hamas, and Fatah', in Art, R.J. and Richardson, L. (eds), Democracy and Counterterrorism: Lessons from the the Past. Washington, DC: Endowment of the United States Institute of Peace.

Giacaman, F. (2013) 'Political representation and armed struggle', Journal of Palestine Studies, 43(1), pp. 24-40.

Gordon, N. (2011) 'Israel's emergence as a homeland security capital', in Zureik, E., Lyon, D. and Abu-Laban, Y. (eds), Surveillance and Control in Israel/Palestine: Population, Territory and Power. New York: Routledge, pp. 153-170.

Guiora, A.N. (2007) 'Quirin to Hamdan: creating a hybrid paradigm for the detention of terrorists', Florida Journal of International Law, 19(2), pp. 511-530.

Hassner, R. (2009) War on Sacred Grounds. New York: Cornell University Press.

'Israel's new Anti-Terror Law violates Arab citizens' human rights' (2016) Adalah. Available at: https://www.adalah.org/en/content/view/8834 (accessed: 15 April 2020).

'Israel's Prevention of Terrorism Ordinance (September 1948)' (1948). Available at: http://www.jewishvirtuallibrary.org/israel-s-prevention-of-terrorism-ordinance-no33-september-1948 (accessed: 23 February 2017).

Jonathan-Zamir, T., Weisburd, D. and Hasisi, B. (2014) Policing Terrorism, Crime Control, and Police-Community Relations. New York: Springer.

Magid, J. (2018) 'How to prevent Jewish and Arab terror', Times of Israel. Available at: https://www.timesofisrael.com/how-to-prevent-terrorism-arab-and-jewish-by-shinbet-commander-who-fought-both/ (accessed: 27 April 2020). 
Morris, B. (2004) The Birth of the Palestinian Refugee Problem Revisited. New York: Cambridge University Press.

Nakhala, D. and Hakala, P. (2012) Israel's Policy of Administrative Detention. European Parliament: Brussels.

Omer-Man, M.S. (2016) 'Will Israel be in a "state of emergency"?' Available at: https://972mag.com/how-administrative-detention-could-keep-israel-in-a-state-of -emergency-forever/120159/ (accessed: 4 March 2017).

Ostrovsky, V. and Hoy, C. (1991) By Way of Deception: A Devastating Insider's Portrait of the Mossad. New York: St Martin's Press.

'Poll: $82 \%$ of Israelis proud of the country, half fear war is near' (2018) Jerusalem Post. Available at: https://www.jpost.com/israels-70th-anniversary/poll-82-percent -of-israelis-proud-of-the-country-half-fear-war-is-near-551239 (accessed: 15 April 2020).

Rabinovich, I. (2015) 'Israel and the changing Middle East', Brookings. Available at: https://www.brookings.edu/blog/markaz/2015/02/06/israel-and-the-changing-midd le-east/ (accessed: 7 January 2021).

Rijke, A. (2020) 'Checkpoint knowledge: navigating the tunnels and Al Walaja checkpoints in the Occupied Palestinian Territories', Geopolitics, pp. 1-22. doi: $10.1080 / 14650045.2020 .1737020$.

Rodman, D. (2013) 'Mossad; spies against Armageddon: inside Israel's secret wars', Israel Affairs, 19(4). doi: 10.1080/13537121.2013.829619.

Rosenzweig, I. and Shany, Y. (2010) 'New Comprehensive Counter-terrorism Memorandum Bill', Israel Democracy Institute. Available at: https://en.idi.org.il/ articles/12147 (accessed: 27 April 2020).

Salzberger, E.M. (2016) 'Counterterrorism law in Israel', conference paper presented at Minerva Center for the Rule of Law under Extreme Conditions, Haifa University. Available at: https://law.haifa.ac.il/images/Counter-Terrorism_Law_and_The_Rule of_Law_Under_Extreme_Conditions_The_Experience_of_Israel.pdf.

Sayigh, Y. (1999) Armed Struggle and the Search for State: The Palestinian National Movement, 1949-1993. New York: Oxford University Press.

'Statistics on Palestinians in the custody of the Israeli security forces' (2020) B'Tselem. Available at: https://www.btselem.org/statistics/detainees_and_prisoners (accessed: 15 April 2020).

'The Constituent Assembly First Knesset 1949-1951, armistice agreements with Egypt, Lebanon, and Jordan' (1949) Jerusalem Center for Public Affairs. Available at: http://www.jcpa.org/art/knesset2.htm.

'The humanitarian impact of the barrier' (2012). Available at: www.ochaopt.org/ documents/ocha_opt_barrier_factsheet_july_2012_english.pdf.

'The ISA Statute' (2020) Shab̄ak. Available at: https://www.shabak.gov.il/english// heritage/Pages/default.aspx\#cbpf=.1994-2000\%23cbp=/SiteCollectionImages/תודוא//202 /semel-sh-new.gif (accessed: 28 April 2020).

'The Six Day War' (2020) Shabak. Available at: https://www.shabak.gov.il/ english//heritage/Pages/default.aspx\#cbpf=.1957-1967\#cbp=/SiteCollectionImages/ מימיהתשש.jpg.

'The State: Israel Defense Forces (IDF)' (2005) MFA. Available at: https://mfa.gov .il/MFA/AboutIsrael/State/Pages/THE STATE- Israel Defense Forces -IDF-.aspx (accessed: 21 March 2017).

'The struggle over the Temple Mount' (2015) Week. Available at: https://theweek.com/ articles/588465/struggle-over-temple-mount (accessed: 15 April 2020). 
Tolan, S. (2018) 'Israel's about-face on Gaza', Foreign Policy, 21 November. Available at: https://foreignpolicy.com/2018/11/21/israels-about-face-on-gaza/ (accessed: 14 April 2020).

'Top 10 arms exporters' (2019) SIPRI. Available at: http://armstrade.sipri.org/ armstrade/html/export_toplist.php (accessed: 14 April 2020).

'Torture and abuse in interrogation' (2017) B'Tselem. Available at: https://www .btselem.org/torture (accessed: 11 April 2020).

Tucker, B.J. (2008) 'Strategies for countering terrorism - lessons from Israeli experience', Counter Insurgency Journal. Available at: https://coincentral .wordpress.com/2008/06/04/strategies-for-countering-terrorism-lessons-from-the-is raeli-experience/ (accessed: 7 January 2021).

Vekstein, D. and Mehrez, A. (1997) 'Technology policy and defense conversion in Israel, 1967-1995', Journal of Technology Transfer, 22(1), pp. 47-56. doi: 10.1007/ BF02509153.

Weisburd, D., Feucht, T., Hakimi, I., Mock, L. and Perry, S. (2009a) To Protect and To Serve: Policing in an Age of Terrorism. New York: Springer.

Weisburd, D., Jonathan, T. and Perry, S. (2009b) 'The Israeli model for policing terrorism', Criminal Justice and Behavior, 36(12), pp. 1259-1278. doi: $10.1177 / 0093854809345597$.

Younes, A. (2018) 'How Mossad carries out assassinations', Al Jazeera. Available at: https://www.aljazeera.com/news/2018/04/mossad-carries-assassinations-180422 152144736.html (accessed: 8 February 2019). 